\title{
An Attempt to Stimulate and Depress the Functional Activity of the Inflammatory Cells from Lesions Experimentally Induced by M. Leprae and M. Lepraemurium
}

\author{
W. A. HADLER \\ (Instituto de Morfologia, Universidade de Campinas, Campinas, Est. S. Paulo, Brasil) \\ A. L. FERREIRA \\ (Departamento de Morfologia da Faculdade de Medicina de Ribeirão Prêto, Ribeirão Prêto, \\ Est. S. Paulo, Brasil) \\ L. M. Z I T I \\ (Instituto de Morfologia, Universidade de Campinas, Campinas, Est. S. Paulo, Brasil)
}

The tissue macrophages of not previously sensitisized guinea pigs are able to lyse $M$. leprae and $M$. lepraermurium already phagocytised by them (Hadler, I 953a); after the lysis takes place they give origin to epithelioid cells. The rate of mycobacterial lysis performed by the tissue macrophages increases as a consequence of previous sensitization (Hadler, I953b, I 955). The rat tissue macrophages, on the other hand, are unable to lyse the phagocytised mycobacteria either previously or after sensitization (Hadler, I 953a; Hadler and Ziti, I 955). They store the bacilli within the cytoplasm and transform themselves into lepra cells.

It was stated (Hadler, I 959) that the injection of electro-negative colloidal particles together with either M. leprae or M. lepraemurium stimulates some functional activities of the macrophages from rat leprosy lesions. There was, as a consequence of the additional effect of the colloidal particles, much evidence supporting the view that the mycobacteria could be readily lysed by the rat tissue macrophages, which further undergo transformation into epithelioid-like cells. Regarding the guinea pig and the rabbit lesions, as a result of the additional effect of the electronegative colloidal particles, there is a slight decrease of the mycobacterial, rate of lysis, accomplished by the macrophages, and therefore a slower rate of evolution of the leprosy lesions takes place.
These findings are interpreted as a stimulant effect of the colloidal particles on the rat macrophage and an opposite eff ect on the guinea pig and rabbit macrophages. They suggest, otherwise the possibility that the functional activity of the inflammatory macrophage might be experimentally changed.

On the basis of these statements, an attempt was made to stimulate and depress the inflammatory cells experimentally produced by mycobacterial inoculation, with the aid of substances already proved to have successful action on the inflammatory reaction. Two kinds of substances have been used for this purpose: corticoid hormones and antihistaminic drugs.

Several steroid hormones from the adre cortex are able to influence the inflammatory reaction (Menkin, I940, I942, I95 I, I953; Selye, I 949a; Kass and Finland, I 953). Some of them, such as cortisone, exert an inhibitory effect (Hench and col., I949; Thorn and col., r 950; Woods and Wood, I950, I 952; Osgood and Favour, I95I ; Michael and Whorthon, I 951; Spain and col., I 952; Taubenhaus, I 953), whereas another one, namely desoxycorticosterone, produces an opposite effect, increasing the

\footnotetext{
*This study was supported by a research grant (E-376o) from the U.S. Department of Health, Education and Welfare of the National Institute of Allergy and Infectious Diseases.
} 
inflammatory reaction (Selye, I 949; Taubenhaus and col., I95I; Rindal, r 953; Taubenhaus, I953). Hormones from the former group were effective in decreasing the rate of evolution of lesions induced by the $M$. lepraemurium (Nagib and Robinson, r956; Takayama, I957; Buttle and col., I 958).

On the other hand, antihistaminic drugs, besides the inhibitory effect on the acute inflammatory reaction (Halpern, I953), decrease the functional activity accomplished by the inflammatory cells (Jancso, I 947; Kátó, I956; Kátó and Gözsy, I956a; Gözsy and Kátó, r 956). As a consequence, they enhance the rate of evolution of experimental tuberculosis (Gözsy and Kátó, I955) and inhibit the natural defence mechanism of guinea pigs against $M$. lepraemurium (Kátó, I957).

TABLE I

Experimental animals and treatments. The animals were inoculated with $M$. leprae and $M$. lepraemurium at a same time, except those concerning with the groups 10, 11, 12 and 13 , which have received only the latter mycobacterial species

\begin{tabular}{|c|c|c|c|c|c|c|c|c|c|}
\hline \multirow[b]{2}{*}{ Group } & \multirow[b]{2}{*}{$\begin{array}{l}\text { Animal } \\
\text { species }\end{array}$} & \multirow[b]{2}{*}{$\begin{array}{l}\text { No. of } \\
\text { animals }\end{array}$} & \multicolumn{2}{|c|}{ INOCULUM } & \multicolumn{2}{|c|}{ TREATMENT $O$} & \multicolumn{3}{|c|}{ FF THE ANIMALS AFTER INOCULATION } \\
\hline & & & $\begin{array}{l}\text { Dose } \\
(m g)\end{array}$ & Route & $\begin{array}{c}\text { Treatment } \\
\text { previous } \\
\text { to } \\
\text { inoculation }\end{array}$ & Drug & $\begin{array}{c}\text { Dose } \\
(m g) \\
(*)\end{array}$ & Route & $\begin{array}{c}\text { No. of injections throughout } \\
\text { the experiment }\end{array}$ \\
\hline I & rat & 20 & 2.0 & $\mathrm{SC}(* *)$ & $98^{\circ} \mathrm{C}-\mathrm{Ih}$ & DCA & I . O & site & at the ist day \\
\hline 2 & rat & 20 & 2.0 & $\mathrm{SC}(* *)$ & $98^{\circ} \mathrm{C}-\mathrm{Ih}$ & DCA & I.O & site & at the ist, i 2 th and the 24 th day \\
\hline 3 & rat & 20 & 2.0 & $\mathrm{SC}(* *)$ & $98^{\circ} \mathrm{C}-\mathrm{Ih}$ & DCA & I. 2 & $\mathrm{p}$ & daily \\
\hline 4 & rat & 20 & 2.0 & $\mathrm{SC}(* *)$ & $98^{\circ} \mathrm{C}-\mathrm{Ih}$ & - & - & - & $-($ control $)$ \\
\hline 5 & rat & 20 & 2.0 & $\mathrm{SC}(* *)$ & $98^{\circ} \mathrm{C}-$ I h & peanut & $\mathrm{I} \mathrm{ml}$ & site & at the ist, i 2 th and the 24 th day \\
\hline 6 & rat & I 5 & I.O & ic & $4^{\circ} \mathrm{C}-6 \mathrm{mon}$ & DCA & I . O & site & at the ist day \\
\hline 7 & rat & I 5 & I. O & ic & $4^{\circ} \mathrm{C}-6 \mathrm{mon}$ & DCA & I.O & site & $\begin{array}{l}\text { daily from the } 7^{\text {th }} \text { until the } \\
37^{\text {th }} \text { day }\end{array}$ \\
\hline 8 & rat & I 5 & I.O & ic & $4^{\circ} \mathrm{C}-6 \mathrm{mon}$ & DCA & I .2 & $\mathrm{p}$ & daily \\
\hline 9 & rat & I 5 & I.O & ic & $4^{\circ} \mathrm{C}-6 \mathrm{mon}$ & - & - & - & $-($ control $)$ \\
\hline IO & rat & 30 & $5 \cdot 0$ & $\mathrm{p}$ & - & DCA & 2.0 & $\mathrm{SC}$ & each two days \\
\hline I I & rat & 30 & $5 \cdot 0$ & $\mathrm{p}$ & - & GORT & 2.0 & $\mathrm{SC}$ & each two days \\
\hline I 2 & rat & 30 & $5 \cdot 0$ & $\mathrm{p}$ & - & - & - & - & $-($ control $)$ \\
\hline I 3 & rat & 30 & $5 \cdot 0$ & $\mathrm{p}$ & - & DDS & 40.0 & oral & daily \\
\hline I 4 & rat & I 5 & 2.0 & $\mathrm{SC}$ & $98^{\circ} \mathrm{C}-\mathrm{Ih}$ & GORT & 2.0 & site & each two days \\
\hline 15 & guinea pig & I 5 & 2.0 & $\mathrm{SC}(* *)$ & $98^{\circ} \mathrm{C}-\mathrm{Ih}$ & DCA & I.O & site & at the ist, i 2 th and $24^{\text {th }}$ day \\
\hline I 6 & guinea pig & I 5 & 2.0 & $\mathrm{SC}(* *)$ & $98^{\circ} \mathrm{C}-$ I h & CORT & I. O & site & at the ist day \\
\hline 17 & guinea pig & I 5 & 2.0 & $\mathrm{SC}(* *)$ & $98^{\circ} \mathrm{C}-\mathrm{Ih}$ & CORT & I.O & site & at the ist, I 2 th and the 24 th day \\
\hline I 8 & guinea pig & I 5 & 2.0 & $\mathrm{SC}(* *)$ & $98^{\circ} \mathrm{C}-\mathrm{Ih}$ & - & - & - & $-($ control $)$ \\
\hline I 9 & rat & IO & 2.0 & $\mathrm{SC}$ & $98^{\circ} \mathrm{C}-\mathrm{Ih}$ & - & - & - & $-($ control $)$ \\
\hline 20 & rat & IO & 2.0 & $\mathrm{SC}$ & $98^{\circ} \mathrm{C}-\mathrm{Ih}$ & $\mathrm{Cl}+\mathrm{Pr}$ & 2.0 & $\mathrm{p}$ & daily \\
\hline $2 \mathrm{I}$ & guinea pig & I 5 & 2.0 & $\mathrm{SC}$ & $98^{\circ} \mathrm{C}-$ Ih & $\mathrm{Cl}+\mathrm{Pr}$ & 2.0 & $\mathrm{p}$ & daily \\
\hline 22 & guinea pig & I 5 & 2.0 & $\mathrm{SC}$ & $98^{\circ} \mathrm{C}-\mathrm{Ih}$ & $\mathrm{Cl}$ & 2.0 & $\mathrm{p}$ & daily \\
\hline 23 & guinea pig & I 5 & 2.0 & $\mathrm{SC}$ & $98^{\circ} \mathrm{C}-\mathrm{Ih}$ & $\operatorname{Pr}$ & 2.0 & $\mathrm{p}$ & daily \\
\hline 24 & guinea pig & I 5 & 2.0 & $\mathrm{SC}$ & $98^{\circ} \mathrm{C}-\mathrm{Ih}$ & - & - & - & $-($ control $)$ \\
\hline
\end{tabular}

(**) The inoculation was carried on 'granuloma pouch' performed by the SELYE (1953) technique.

(*) Dose for each roog of body weight.

SC: subcutaneous.

ic: intracutaneous.

$\mathrm{p}$ : peritonea!.

site: injection performed on the site of inoculation.
DCA: desoxycorticosterone acetate (peanut oil solution). CORT: cortisone (water solution).

Cl: chlorpromazine: IO-(-dimethylaminopropyl) 2chlorophenotiazine.

Pr: prometazine: dimethylamino-2-propil-N-thiodiphenylamine hydrochloride.

DDS : 4, 4' -diaminediphenysulphone. peanut: peanut oil. 
MATERIAL AND METHODS

Adult guinea pigs and rats of both sexes, weighing respectively $300-350$ and $130-200$, were inoculated with $M$. leprae and $M$. lepraemurium suspensions, and prepared by the usual techniques, and rendered free of tissue particles with the aid of the Hanks ( I95 I) technique slightly modified. The route of inoculation, the dose of inoculum and the treatment performed on the bacilli previously to inoculation, are given in Table I. The dose of the inoculum was determined from the weight of already dried bacilli, derived from a suspension sample. Either killed $\left(98^{\circ} \mathrm{C}\right.$ for $\mathrm{I} \mathrm{h}$ and $4{ }^{\circ} \mathrm{C}$ for 6 months) or living bacilli were used. The animals injected subcutaneously and intracutaneously have received $M$. leprae at one side and $M$. lepraemurium at the other side.

After inoculation the animals were treated as shown in Table I. Some of them have received corticosteroid hormones, whereas others have been injected with an antihistaminic drug (prometazine) alone or mixed with a hypometabolic drug (chlorpromazine).

Every two days one or two animals of each group were killed by ether inhalation and the site of inoculation was excised for histological examination. From the animals peritoneally inoculated pieces of liver, spleen, lymph nodes and lungs were excised for histological studies. The histological study was carried out on material fixed in Bouin's fluid, embedded in paraffin and stained by HE., Masson's trichromic, azur II - eosin and the Faraco (1938) modification of Ziehl-Neelsen technique.

From the group Io, I I, I 2 and I 3,20 animals were kept until natural death, to provide data for the study of the effect of treatment on the animal survival.

\section{RESULTS}

The results were based on histological comparison of the inflammatory cells or the bacillary amount, as between treated and control animals. The control animal lesions will not be described, since they were carefully studied elsewhere (Hadler, I 953; Hadler and Ziti, I955).

$D C A$ effect - the DCA injection performed into the lesion increases the acute inflammatory re- action induced by $M$. leprae and $M$. lepraemurium either on guinea pigs or on rats. The lesions become larger and always display a central abscess (Figs. I and 2), surrounded by the inflammatory tissue, where further a greater connective fibrocytic reaction takes place. The development and the rate of evolution of the lesions are shorter in treated rather than in control animals.

Regarding the guinea pig lesions they remain tuberculoid in type, where the macrophages are able to lyse the phagocytised mycobacteria and to develop into epithelioid cells.

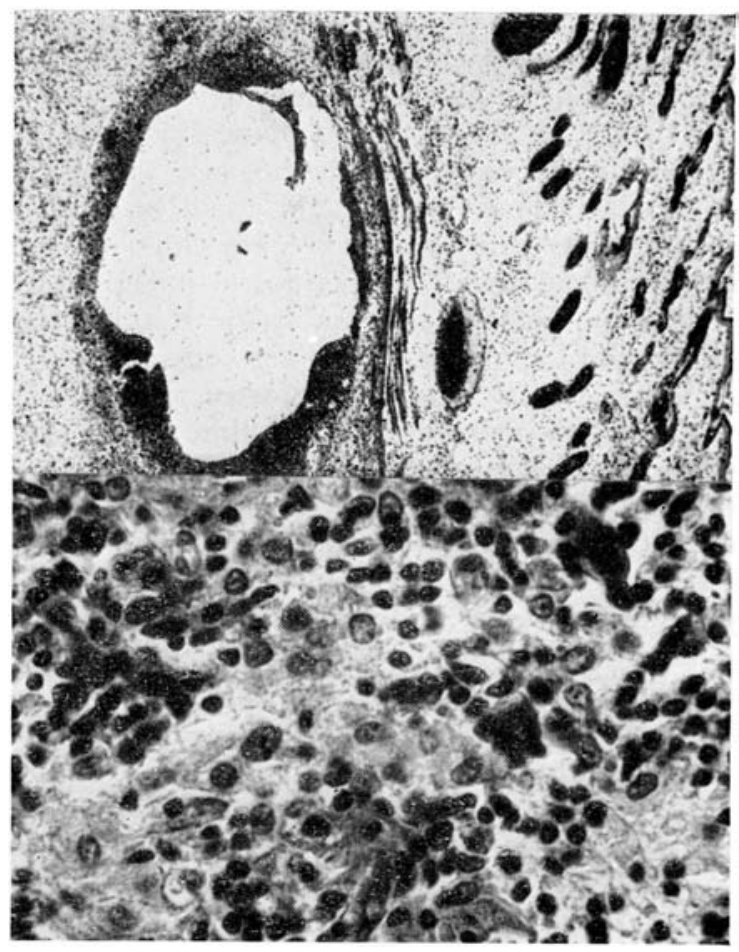

FIG I Rat subcutaneously inoculated with $M$. lepraemurium and topically treated with desoxycorticosterone acetate; HE, 5oX. Central abcess surrounded by the inflammatory tissue; two days after mycobacterial inoculation.

FIG 2 Rat subcutaneously inoculated with $M$. leprae and topically treated with desoxycorticosterone acetate, Masson's trichromic, 500X. Macrophages showing signs of damage to cytoplasm and nuclei; ro days after inoculation. 
The lesions of treated rats, on the other hand, display some histological changes compared to the control animals. Although most of the lesions are lepromatous in histology, where the macrophages are unable to lyse the phagocytised bacilli and therefore they transform themselves into lepra cells, there are some areas inside the lesions where the structure becomes altered. In these areas the macrophages (Fig. 2) display evidence of cell damage (striking cytoplasmic vacuolization; nuclear pyknosis), and contain only a few bacilli within the cytoplasm. The phagocytised bacilli show striking morphological alterations; they lose their alcohol-acid resistance and become progressively less numerous. Simultaneously, the macrophages transform themselves into epithelioid-like cells, without bacilli within the cytoplasm, suggesting that they are able to lyse the phagocytised bacilli.

The described histological changes only occur in well limited areas of the lesions near the place where DCA was injected and could be better seen when DCA was injected many times on the site of inoculation. The peritoneal injection of DCA was ineffective so far as the histological changes of cutaneous lesions are concerned.

As the DCA treatment was started 7 days after the bacillary inoculation, at a time when the control rat lesions already displayed some lepra cells, an acute inflammatory reaction took place into the lesions. At the same time some lepra cells and macrophages showed signs of cytoplasmic and nuclear damage. Four days later some epithelioid-cells without bacilli inside appeared in the lesion.
The injection of peanut oil alone, does not produce any change concerning the histological structure either of rat or of guinea pig lesions.

Table 2 shows the results concerning the survival of rats inoculated with living $M$. lepraemurium and treated with DCA (group io in Table $\mathrm{I}$ ). The comparison between the mean of survival of these animals and that concerning the untreated control group, carried on through the analysis of variance, shows no significant differences. Histologically there are no changes in the lesions of treated animals in comparison to the control ones; both show a large amount of active lesions, very rich in bacilli, six months after inoculation.

Cortisone effect - The injection of cortisone either together with the bacilli suspension or into the lesion throughout its development, inhibits the acute inflammatory reaction induced by $M$. leprae and $M$. lepraemurium and decreases the rate of the evolution of the lesion. Such cortisone effect is better seen in the guinea pig lesions.

The lesions of cortisone treated rats are smaller than those of untreated controls and formed by lepra cells, containing a large amount of bacilli within the cytoplasm.

The guinea pig lesions, however, besides longer development and evolution, show some histological changes as an effect of cortisone treatment. The mycobacteria are soon phagocytized by blood leucocytes and tissue macrophages suggesting an increase in the phagocytic activity of these cells. The phagocytized bacilli remain stored within the macrophage cytoplasm for a much longer time than they do in the homo-

TABLE 2

\begin{abstract}
Mean of survival of rats inoculated with $M$. lepraemurium. Effect of cortisone, desoxycorticosterone (DCA) and DDS (4, 4'-diaminodiphenylsulfone) treatment. The DDS treated group provides data concerning the effect of an active drug on the animal survival
\end{abstract}

\begin{tabular}{|c|c|c|c|c|c|c|c|}
\hline & & & & \multicolumn{3}{|c|}{ Treatments } & \multirow{2}{*}{ Control } \\
\hline & & & & Cortisone $(*)$ & $\operatorname{DCA}(*)$ & $\operatorname{DDS}(* *)$ & \\
\hline Number of animals ... & . & . & . & 20 & 20 & 20 & 20 \\
\hline Mean of survival (days) & $\ldots$ & . & . & $228 \cdot 3 \pm 3 \cdot 5$ & $229 \cdot 5 \pm 4 \cdot 0$ & $3^{8} 3 \cdot 0 \pm 9 \cdot 2$ & $237 \cdot 4 \pm 3 \cdot 9$ \\
\hline
\end{tabular}

(*) Treatment started at the first day after inoculation.

(**) Treatment started at the 7 th day after inoculation. 
logous cells of control lesions. On the other hand, there is no macrophage damage in the greater part of treated lesions, in spite of the large amount of bacilli within the cytoplasm. Further, two different modes of behaviour of the containing bacillary macrophage could be seen: (a) the bacilli remain stored within the cytoplasm of the macrophage and the cell becomes morphologically similar to the lepra cell, containing a large amount of bacilli and arranged as in leprosy histology; (b) the bacilli are lysed by the macrophage that further undergoes transformation into the epithelioid cell, without bacilli within its cytoplasm. The former macrophage behaviour is more frequently found near the central abcess, at a place where cortisone was injected; the latter were seen in lesion areas far from the abscess, suggesting some correlation between concentration and cortisone effect.

In the lesion areas where the bacillary lysis seems to occur there is cytological evidence of macrophage damage and the mycobacteria show deep morphological alterations.

The cortisone treatment performed subcutaneously on rats peritoneally inoculated with living $M$. lepraemurium does not show any effect on animal survival (Table 2). Furthermore histologically the leprosy lesions of treated animals do not differ from those of control ones.

Chlorpromazine and prometazine effect - This effect is similar to that of cortisone. It appears as an inhibition of the acute inflammatory reaction mainly found in guinea pig lesions. Moreover, the rat treated lesions are also smaller than the control. They are formed by lepra cells, arranged as a lepromatous structure, like the control lesions.

The rate of evolution of treated guinea pig lesions is slower than those of the controls. In the former lesions, the inoculated mycobacteria are sooner phagocytised by macrophages, but remain stored within the cytoplasm, without any evidence of bacillary lysis and of cell damage, in the greater part of the lesion. The bacilli-laden macrophages transform themselves into lepralike cells (Figs. 3 and 4), containing a large amount of well preserved bacilli. These cells are arranged as a lepromatous-like structure. Only in very limited lesion areas are there morphologi-

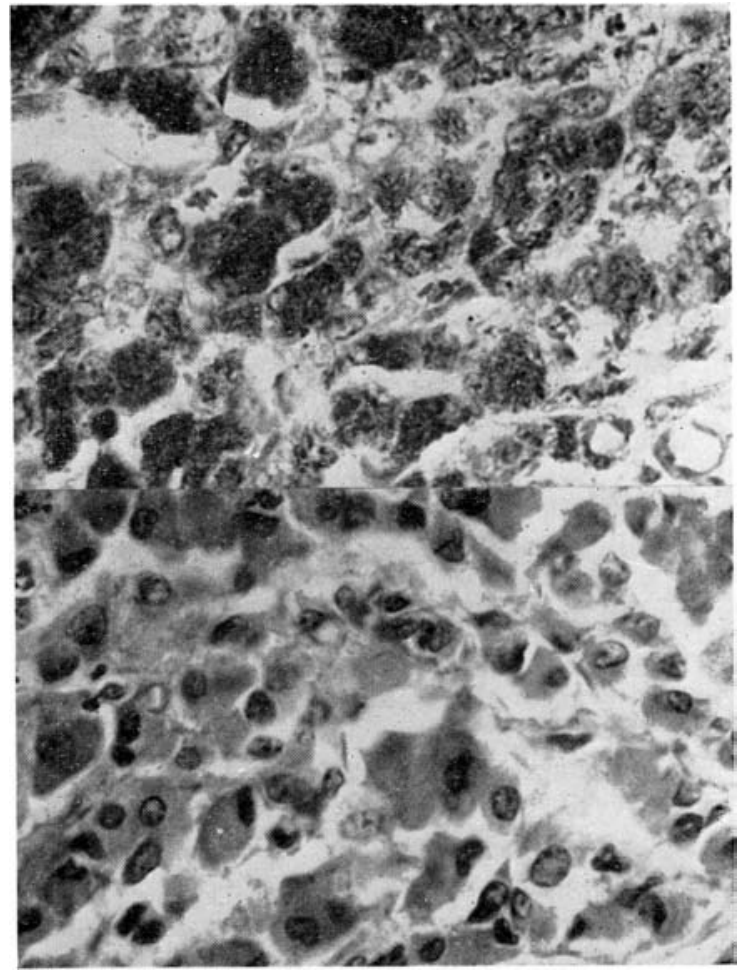

FIGS. 3 and 4 Guinea pig subcutaneously inoculated with M. lepraemurium treated by chlorpromazine-prometazine; $560 X$. Lepra-like cells stained by $\mathrm{HE}$ and by ZiehlNeelsen, showing a great amount of bacilli within its cytoplasm; 20 days after inoculation.

cal evidences of mycobacterial lyses and of macrophage damage, until the 3oth day of the lesion evolution, in contrast with what happens in the lesions of control animals, where evidences of bacillary lysis can be seen sooner.

The findings concerning the effect of either chlorpromazine or prometazine injected alone support the view that both are active. Nevertheless, it appears that these two substances used together seem to be more effective at an equal dose (interaction).

\section{DISGUSSION}

Two distinct and opposite effects could be established with the substances used by us: (I) an increase of the acute inflammatory reaction followed by a functional stimulation of the tissue 
macrophages, elicited by desoxycorticosterone acetate; (2) a decrease of the acute inflammatory reaction followed by a partial inhibition of the activity of the tissue macrophages, as a consequence of cortisone and chlorpromazine plus prometazine treatment.

The first effect could be well observed in rat lesions, where some macrophages seems to acquire, as a consequence of the treatment, the ability to lyse the phagocytised mycobacteria. As a result, the histological structure of the lesions is affected and some tuberculoid-like areas containing epithelioid-like cells do occur. The lysis of bacilli seems to act in parallel with the macrophage damage, supporting the view that DCA treatment enhances the bacilli-macrophage interaction.

On the other hand, the second effect was better seen in the guinea pig lesions, where a partial inhibition of the macrophage activity is responsible for the decrease of the mycobacterial rate of lysis. As a consequence the macrophages store a great amount of bacilli and become morphologically similar to the lepra cells.

Both effects show that the two main structural types of leprosy lesions might be affected by drugs.

Several results concerned with the effect of corticosteroid hormones on inflammatory lesions support our interpretation. Cortisone appears to accomplish their effect on the inflammatory cells by inhibiting its physiological activity (Menkin, I $953 \mathrm{a}$; I 953b). As a consequence, although the actual rate at which the $M$. tuberculosis is phagocytosed by the macrophages remains normal after treatment, the number of mycobacteria within each cell is greater than normal, since the digestive capacity of the macrophages decreases (Kass and col. I953; Lurie, I955; Lurie and Zapparodi, I955). This effect is responsible for the latter appearance of the epitheliod cell, as we have observed in the lesions of guinea pigs inoculated with $M$. leprae and $M$. lepraemurium and treated by cortisone. This effect seems to depend upon the action of cortisone that decreases the cellular metabolism and further the cellular activities (Kass and Finland, I 953).

Nevertheless, cortisone acts by increasing the rate of evolution of the rat tuberculosis, the disease becoming therefore able to kill the animals so treated (Michael and col., r 950). Concerning the murine leprosy, our findings show that cortisone does not modify the rate of evolution of the disease. This result suggests that the general defence mechanism against $M$. lepraemurium is not effected by cortisone treatment, in contrast to what happens with $M$. tuberculosis.

It was pointed out that the phagocytoses of $M$. lepraemurium by tissue macrophages either of rats or of guinea pigs is not influenced by antihistaminic drugs (Kátó, I956). This statement is in agreement with our results concerning chlorpromazine-prometazine treatment. Antihistaminic treated guinea pigs display lesions whose histological structure is similar to those of rats (Kátó, I 957); that is also confirmed by our findings. Nevertheless, either the antihistaminic drug prometazine or the chlorpromazine, which is admitted to be effective as if it decreases the cellular metabolism (Laborit and Huquenard, I952; Decourt, I955), produce a similar effect. Both seem to be able to inhibit the mycobacterial lysis accomplished by the macrophages, but they would act by different mechanisms.

The cortisone and antihistaminic effects may be correlated, since some adrenal corticoids inhibited the histaminic liberation by the tissues (Ungar, I 944; Halpern, I 953; Ashi, Funaki and Ono, I955), increasing the amount of antifibrinolysine (Ungar, Damgaard and Hummel, I 95 I). Such effect would depend upon the decreasing of mycobacteria-host cell interaction which could be considered as very important concerning the enzyme biosynthesis. Some of these enzymes would be responsible for the mycobacterial lyses. We admit that cortisone and chlorpromazine-prometazine treatment inhibits the synthesis of lytic enzymes by the macrophages. Desoxycorticosterone acetate would show an opposite effect, since it seems to increase the mycobacteria-host cell interaction which stimulates the synthesis of lytic enzymes by the macrophages.

Our findings show, otherwise, that the functional activity of some leprosy lesion cells could be experimentally altered, which produces a striking change in the histological structure of the lesions.

\section{SUM MARY}

The attempt to produce an experimental change in the functional activity of the macrophages from guinea pig and rat lesions induced by 
$M$. leprae and $M$. lepraemurium was made with the aid of adrenal corticoid hormones, an antihistaminic drug and a substance that is admitted to depress the cell metabolism.

The findings showed that two opposite effects could be traced, such as:

(I) Cortisone and chlorpromazine-prometazine treatment besides a decrease of the acute inflammatory reaction, exert an inhibitory effect upon the activity of the tissue macrophages. As a consequence there is a decrease of mycobacterial rate of lysis by the macrophages which readily become able to store a great amount of bacilli inside their cytoplasm. This effect could be well seen in guinea pig lesions, where cells similar to the lepra cells do appear after treatment, allowing a marked alteration of the histological structure of the lesion. A lepromatous-like structure emerges in guinea pig treated lesions, whereas a tuberculoid structure arises in untreated ones.

(2) Desoxycorticosterone treatment in contrast increases the acute inflammatory reaction and stimulates the tissue macrophages, as could be established in the rat lesions. As a consequence, some rat macrophages become able to lyse the phagocytized mycobacteria, which allows of the development of some areas containing epithelioidlike cells, without bacilli within the cytoplasm.

Both effects show that the two structural kinds of lesions induced by $M$. leprae and $M$. lepraemurium might be affected by treatment that influences the mycobacteria-host cell interaction. This interaction would be related to the biosynthesis of enzymes, some of which have lytic properties concerning the phagocytised mycobacteria.

\section{R E S U M O}

Tentou-se modificar experimentalmente a atividade funcional dos macrófagos de lesões produzidas em cobaios e ratos, pelo $M$. leprae e pelo $M$. lepraemurium, mediante o emprêgo de corticóides da adrenal, de um antihistamínico e de uma substância que se admite deprimir o metabolismo celular. Os resultados mostraram que dois efeitos opostos foram obtidos:

(I) O tratamento efetuado com cortisona ou com a mistura clorpromazina-prometazina, além de diminuir a reação inflamatória aguda apresenta ação inibidora sôbre a atividade dos macrófagos dos tecidos lesados. Consequente- mente, diminui a velocidade de lise das micobactérias pelos macrófagos, os quais tornam-se capazes de armazenar grande número de bacilos no citoplasma. Ésse efeito é melhor observado nas lesões de cobaios, nas quais surgem células semelhantes à célula leprosa, responsáveis por intensas alterações estruturais das lesões. Ocorre estrutura de tipo lepromatoso nas lesões submetidas a tratamento, enquanto que nos animais não tratados as lesões são de tipo tuberculóide. (2) O tratamento pela desoxicorticosterona, ao contrário, intensifica a reação inflamatória aguda e estimula o macrófago tissural - conforme foi verificado em lesões do rato. Como decorrência, alguns macrófagos do rato tornamse aptos em lisar as micobactérias fagocitadas, provocando o aprecimento de algumas áreas contendo células semelhantes às epitelióides, isentas de bacilos.

Êsses efeitos mostram que os dois tipos estruturais encontrados nas lesões provocadas pelo $M$. leprae e pelo $M$. lepraemurium podem ser alterados por substâncias que atuam na interação entre as micobactérias e as células do hospedeiro. A referida interação parece responsável pela biosíntese de enzimas, algumas das quais seriam líticas para as micobactérias fagocitadas.

\section{B I B L I O G R A P H Y}

Buttle, G. A. H., D'ARcy, P. F. and howard, E. M. The influence of cortisone and hydrocortisone acetates on the course of Mycobacterium lepraemurium infection in rats. British J. Pharmacol. and Chemoth. 13, 95-97, 1958.

DECOURT, P. Narcobiotic activity and mode of action of chlorpromazine. Anaesthesia 1o, 22 I-232, 1955.

FARACo, J. Bacilos de Hansen e cortes de parafina: método complementar para pesquisa de bacilos de Hansen em cortes de material incluído em parafina. Rev. Brasil. Leprol., 6, I 77-186, I 938.

GOZsY, B. and KATO, L. Studies on the effects of phagocytic stimulation on microbial diseases. III. Influence of antihistamines and I.4-dimethyl-7-isoporpilazulene on experimental tuberculosis. Canad. J. Microbiol., r, 46 I-469, I 955. GOzsY, B. and KATO, L. Some factors decreasing phagocytic activity of monocytes against tubercle bacilli, strain BCG. Canad. J. Biochem. and Physiol., 34, 580-586, 1956.

HADleR, W. A. Comportamento do cobaio e do rato normais injetados com 'lepromina' por via intradérmica. Rev. Brasil. Leprol. 21, I65-194, i 953 a.

HADLER, W. A. Estudo comparado das lesoes provocadas pela injeçao intradérmica de suspensoes de $M$. leprae e M. tuberculosis em cobaios normais. Rev. Brasil. Leprol. 21, 3 I 5-340, I 953 b.

HADleR, w. A. Influência da inoculaçao prévia de BCG sôbre os resultados da reaçao da lepromina em cobaios. Bol. Serv. Nac. Lepra, 15, 5-62, 1955. 
HADLER, W. A. 'The action of electro-negative colloidal particles on the inflammatory reaction induced by $M y c o-$ bacterium leprae and $M$. lepraemurium in rats, guinea pigs and rabbits. Rev. Basil. Leprol. 27, 9-I 5, I 959.

HADler, W. A. and ziti, L. M. Estudo da reaçao da lepromina no rato prèviamente inoculado com $M$. lepraemurium e com M. tuberculosis (BCG). Rev. Brasil. Leprol. 23, $53-75$, I 955 .

HALPERN, B. N. Histamine, antihistaminiques de synthese et procesus inflammatoires - in Mechanism of Inflammation. Acta Inc. Med. Publ. Montreal, I953.

HANks, J. H. Bacteriology of leprosy. Ann. N. York Acad. Sci. 54, I 2-19, I95 I.

HAYASHI, H., FUNAKI, T. and ONO, T. Influence of cortisone acetate on increased capillary permeability induced by leucotaxine. Mie Med. J. 4 (suppl. 2) : I I I-I I8, I 955. HENGH, P. S., KendAll, E. C., SlOGUmb, C. H. and POlley, H. F. The effect of a hormone of the adrenal cortex (I 7hydroxy-I I-dehydrocorticosterone: Compound E) and of pituitary adrenocorticotropic hormone on rheumatoid arthritis. Proc. Staff Meet. Mayo Clin. 24, I81-184, I 949. JANCSO, M. Histamine as physiological activator of reticuloendothelial system. Nature. 160, 227-228, 1947.

KASS, E. H. and FINLAND, M. Adrenocortical hormones in infection and immunity. Ann. Rev. Microb. 7, 36I-388, I 953 .

кATO, L. Experimental transmission of murine leprosy to the guinea pig by means of induced macrophage exsudate and suspension of natural defense mechanism. Internat. J. Leprosy, 25, 193-206, 1957.

KATO, L. and GOZSY, B. Action of histamine and antihistamine on the ingestion of murine leprosy bacilli by macrophages of the rat and the guinea pig. Insternat. J. Leprosy, 24, 447-455, I 956.

KATO, L. and GOzsy, B. Role of histamine and leucotaxin on function of cellular defense mechanism. Am. J. Physiol. 184, 296-300, I 956a.

LABORIT, H. and HUQUENARD, P. Technique actuelle de l'hibernation artificielle. Presse Medicale. 6o, I 455-1 456, I 952 .

LURIE, м. в. On the role of hormones in experimental tuberculosis. Adv. Tuberc. Res. (Basel, New York). 6, I 8-48, I 955 .

LURIE, M. B. and ZAPPASODI, P. On the mode of action of cortisone on the pathogenesis of tuberculosis and its implication for the nature of genetic resistance to the disease. In Experimental Tuberculosis. Ciba Found. Symp. 246-260, I 955 .

MENKIN, v. Effect of adrenal cortex extract on capillary permeability. Am. J. Physiol., 129, 691-702, i 940.

MENKIN, v. Further studies on the effect of adrenal cortex extract and of various steroids on capillary permeability. Proc. exp. Biol. and Med., 51, 39-48, 1942.

MENkin, v. Effects of cortisone on the mechanism of increased capillary permeability to Trypan blue in inflammation. Am. J. Physiol. r66, 509-5 I 7, I95 I.

MENKIN, v. Effect of some steroids and of corticotropin (ACTH) on cellular activity. Proc. Soc. exp. Biol. and Med. 82, I 89-194, I953.

MENKIN, v. Recent studies on repair and on the mechanism of suppression by anti-inflammatory steroids. In mechanism inflammation. Acta Inc. Med. Publ. Montreal, pg. I37I 59, I 953 .

michael, m. JR., CUmmings, м. м. and Bloom, w. L. Course of experimental tuberculosis in the albino rats as influenced by cortisone. Proc. Soc. exp. Biol. and Med. 75, 6r $3-6$ I6, I 950 .

michael, M. JR., and whorton, c. M. Delay of early inflammatory response by cortisone. Proc. Soc. Biol. and Med. 76, 754-756, I 95 I.

NAGUib, M. and Robson, J. M. The effect of cortisone alone and in combination with isoniazid on experimental murine leprosy in mice. British J. Pharm. and Chemoter. 11, 326-329, I 956.

OSGOOD, C. K. and FAvOUR, C. B. The effect of adrenocorticotropic hormone on inflammation due to tuberculin hypersensitivity and on circulating antibody levels. J. Exp. Med. 94, 4I 5-430, I 95 I.

RINDANI, T. H. Studies on the influence of topical reticuloendothelial blockade and of topical administration of various steroids on inflammation. In Mechanism of Inflammation. Acta Inc. Med. Publ., Montreal, pg. I03I 08, 1953 .

SELYE, H. Further studies concerning the participation of the adrenal cortex in the pathogenesis of arthritis. Brit. Med. J. 19, I I 29-I I 32, I 949.

SELYE, H. Effect of ACTH and cortisone upon 'anaphylactoid reaction'. Canad. Med. Ass. J. 6r, 553-556, I 949.

SELYE, H. Use of 'granuloma pouch' technic in the study of antiphlogistic corticoids. Proc. Soc. exper. Biol. and Med. 82, 328-333, I 953 .

SPAin, D. M., Molomut, N. and haber, A. Studies of cortisone effects on inflammatory response; alteration of histopathology of chemically induced inflammation. J. Lab. and Clin. Med. 39, 383-389, 1952.

TAKAYAMA, Y. The influence of X-ray and administration of cortisone and other drugs upon the onset of murine leprosy. La Lepro. 26, 8-1 4, 1957.

TABENHAUS, M. Further studies of the hormonal regulation of granulation tissue formation. In mechanism of Inflammation. Acta Inc. Med. Publ., Montreal, pg. 97-ıoo, I 953 .

TAUBENhAUS, M., TAYLOR, B. and MORTON, J. v. Hormonal interaction in regulation of granulation tissue formation. Endocrinol. 51, I83-191, I952.

THORN, G. W., FORSHAM, P. H., FRAWLEY, F. T., HILl, S. R. JR, ROCHE, M, STAEHElin, D. and WILSON, D. L. Medical progress; clinical usefulness of ACTH and cortisone. New England J. Med. 242, 783-793; 824-834; $865-872$, I 950 .

UNGAR, G. Inhibition of histamine release by pituitaryadrenal mechanism. J. Physiol. 103, 333-343, I 944.

UNGAR, G., DAMGAARD, E. and HUMMEL, F. P. Fibrinolysinantifibrinolysin system in serum: mechanism of its endocrine control. Endocrinol. 49, 805-816, I951.

woods, A. C. and wood, R. M. Action of ACTH and cortisone on experimental ocular inflammation. Bull. Johns Hopkin Hosp. 87, 482-504, I950.

woops, A. C. and wood, R. M. Effect of cortisone and ACTH on ocular inflammation secondary to injection of irritant substances. Bull. Johns Hopkin Hosp. 9o, I 34-I 48, I 952 .

\section{70 Leprosy Review}

